\title{
Genetic Diversity of Croton L. (Euphorbiaceae) in Thailand
}

\author{
Puangpaka Soontornchainaksaeng ${ }^{1, *}$, Pranom Chantaranothai ${ }^{2}$ \\ and Chadaporn Senakun ${ }^{3}$ \\ ${ }^{1}$ Department of Plant Science, Faculty of Science, Mahidol University, \\ Rama VI Rd., Pyathai, Bangkok, Thailand, 10400 \\ ${ }^{2}$ Applied Taxonomic Research Center, Department of Biology, Faculty of Science, Khon Kaen University, \\ Khon Kaen 40002, Thailand \\ ${ }^{3}$ Walairukhavaj Botanical Research Institute, Mahasarakam University, \\ Mahasarakam, Thailand
}

Received July 31, 2003; accepted October 3, 2003

\begin{abstract}
Summary Genetic diversity of Croton 15 species were investigated. The results revealed that chromosome numbers of Croton are quite unique of $2 n=20$, except $C$. hirtus which contains $2 n=16$. Chromosome numbers of 9 species are the first recorded. The genus Croton has base number of 8 and 10. Chromosomes of microsporocytes of Croton are very well stained with propionocarmine. Most of them are clearly paired in bivalent of $1.00-6.00 \mu \mathrm{m}$ at metaphase I cells of $26.67-63.33 \mu \mathrm{m}$ (Ø). Chromosomes are balanced disjunction at anaphase I. The results show that Croton are very good fertile and stable in natural habitat and it has a small genome which could be manipulated or improved simply. C. hirtus is probably more advanced than the others.
\end{abstract}

The genus Croton L. comprises over 800 species, it is one of the most widely distributed genus in pantropics, mainly in the Neotropics and Madagascar. Thirty species of Croton found in Thailand (Chayamarit et al. 2001). Most of them are used as medicinal plants except $C$. delpyi which is used as wood.

The chromosome number can provide significant information about the plant modes of reproduction, evolutionary history and the genetic relationships between closely related species. As Thailand is a fast growing of the population therefore, rapid of road development and the demand for using land are increasing. Deforestation causes rapidly number of wild useful species decrease. To prevent the extinction of species and loss of genetic diversity, conservation and the study of genetic diversity, of available species is needed. The data from genetic diversity will support to plant improvement, phylogenetic and taxonomic studies and the trend of conservation strategies. There are 12 previous records of chromosome numbers of Croton (Table 1).

\section{Materials and methods}

Genetic diversity of 15 Thai Croton species was studied. Young flower buds were obtained from natural populations in several sites of Thailand and fixed in Carnoy's solution. The chromosomes were made by propionocarmine squash technique. Cytogenetic study was made from well spread chromosomes in various stages of pollen mother cells. Chromosome number and meiotic figures were determined from 25 cells, examined using $\times 100$ magnification (Olympus-BHA, LM) and the best cells were photographed using an oil emersion objective. Voucher specimens are deposited at the herbaria of Department of Plant Science, Mahidol University, Department of Biology, Khon Kaen University and the Royal Garden Suanluang, Rama IX, Bangkok.

\footnotetext{
* Corresponding author, e-mail: scpsi@mahidol.ac.th
} 


\section{Results}

Chromosomes of microsporocytes of Croton are very well stained with propionocarmine. Most of them are clearly paired in bivalent about $1.00-6.00 \mu \mathrm{m}$ in first metaphase cells of $26.67-63.33 \mu \mathrm{m}$. The chromosome numbers of the species studied are presented in Table 2, and Fig. 1. All species studied have $2 n=20$, except $C$. hirtus which contains $2 n=16$. Their base numbers are concluded for $x=8$ and 10 .
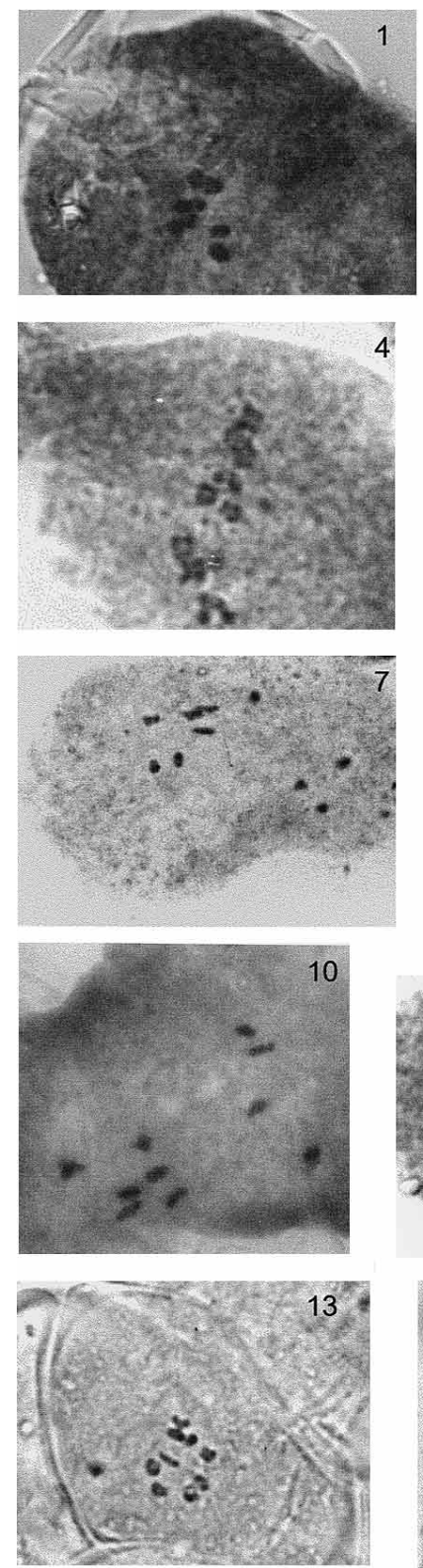

2
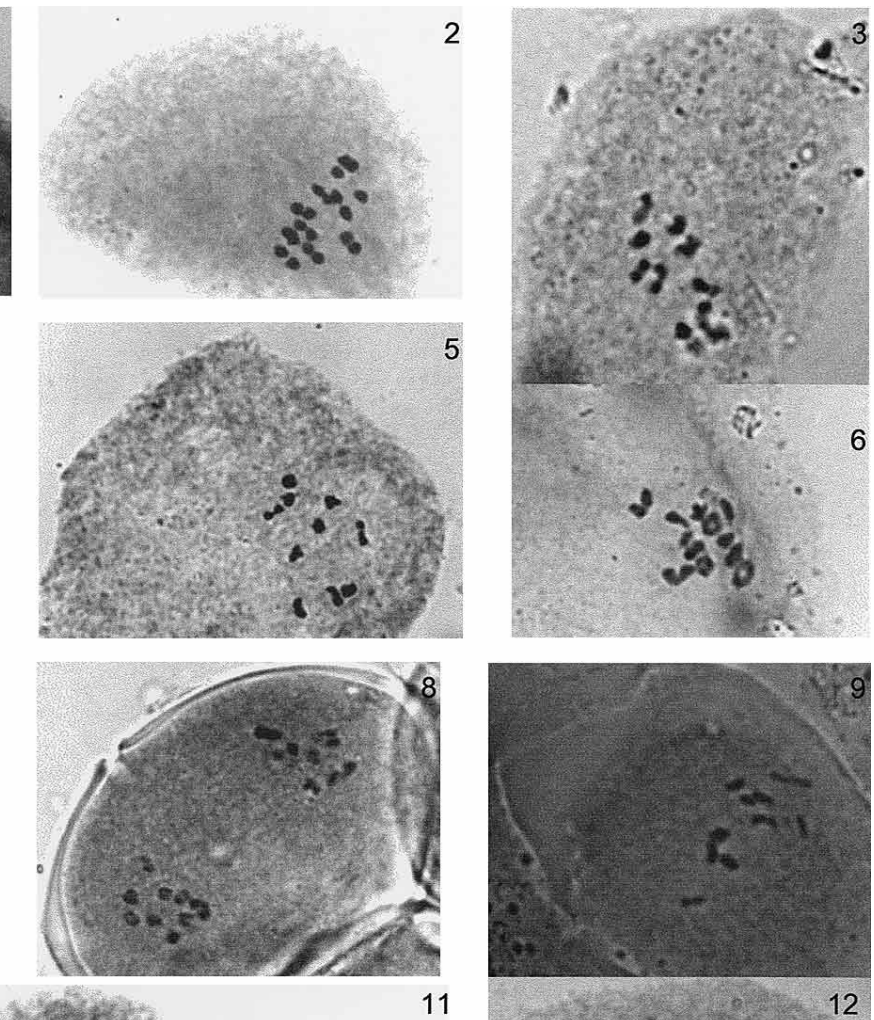

11
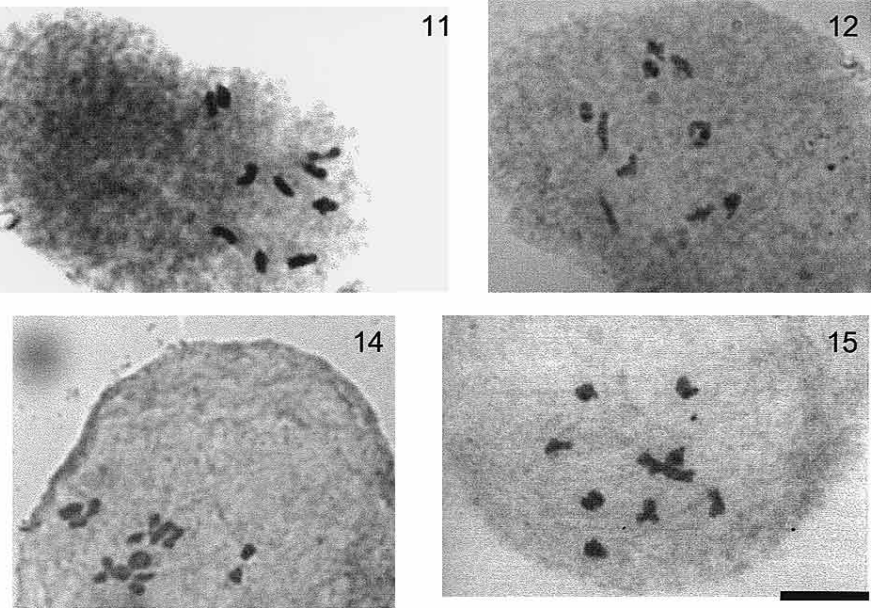

Fig. 1. 1-15) Pollen mother cells of Croton at metaphase I and anaphase I. 1) C. hirtus $(2 n=16)$, 2-14) $2 n=20$; 2) C. bonplandianus, 3) C. cascarilloides, 4) C. caudatus, 5) C. hutchinsonianus, 6) C. kerrii, 7) C. kongensis, 8) C. poilanei $(10: 10)$ at anaphase I, 9) C. robustus, 10) C. roxburghii, 11) C. stellatopilosus, 12) C. thorellii, 13) C. tiglium, 14) Croton sp. 1, 15) Croton sp. 2. Bar represents $10 \mu \mathrm{m}$. 
Table 1. Previous records of chromosome numbers of Croton

\begin{tabular}{|c|c|c|c|}
\hline \multirow{2}{*}{ Species } & \multicolumn{2}{|c|}{ Chromosome number } & \multirow{2}{*}{ Authors } \\
\hline & G & $\mathrm{S}$ & \\
\hline \multirow[t]{2}{*}{ 1. C. bonplandianus } & - & 20 & MBG (1999) \\
\hline & 10 & - & Soontornchainaksaeng and Chaiyasut (1999) \\
\hline 2. C. dioicus & 14 & - & MBG (1999) \\
\hline 3. C. glandulosa & - & 16 & Perry (1943) \\
\hline 4. C. rolentzii & 10 & - & MBG (1999) \\
\hline 5. C. monanthogynus & - & 16 & Perry (1943) \\
\hline 6. C. palmeri & - & 16 & Perry $(1943)$ \\
\hline 7. C. robustus & 10 & - & Soontornchainaksaeng and Chaiyasut (1999) \\
\hline 8. C. sarcopetalus & 32 & - & MBG (1999) \\
\hline 9. C. spasiflorus & 10 & - & MBG (1999) \\
\hline 10. C. subblyratus* & 10 & - & Soontornchainaksaeng and Chaiyasut (1999) \\
\hline 11. C. tiglium & 10 & - & Soontornchainaksaeng and Chaiyasut (1999) \\
\hline 12. C. wigginsii & 14 & - & MBG (1999) \\
\hline
\end{tabular}

G: gametophytic count, S: sporophytic count.

$*$ C. subblyratus $=$ C. stellatopilosus.

Table 2. Chromosome numbers and meiotic figures of Thai Croton

\begin{tabular}{|c|c|c|c|c|c|c|c|}
\hline \multirow{2}{*}{ Species } & \multicolumn{3}{|c|}{ Chromosome number } & \multirow{2}{*}{$\begin{array}{l}\text { Meiotic } \\
\text { figure }\end{array}$} & \multirow{2}{*}{ Record } & \multirow{2}{*}{ Locality } & \multirow{2}{*}{ Coll. no. } \\
\hline & $2 n$ & $n$ & $x$ & & & & \\
\hline 1. C. bonplandianus Baillon & 20 & 10 & 10 & $10 \mathrm{II}$ & Prev. & Prachuap Khiri Khan, Kalasin & $087,161^{*}$ \\
\hline 2. C. cascarilloides Raeusch. & 20 & 10 & 10 & $10 \mathrm{II}$ & $1 \mathrm{st}$ & Songkhla & 285 \\
\hline 3. C. caudatus Geiseler & 20 & 10 & 10 & $10 \mathrm{II}$ & $1 \mathrm{st}$ & Sa Kaeo & \\
\hline 4. C. hirtus L. Her. & 16 & 8 & 8 & $8 \mathrm{II}$ & $1 \mathrm{st}$ & Ubon Ratchathani & $160 *$ \\
\hline 5. C. hutchinsonianus Hosseus & 20 & 10 & 10 & $10 \mathrm{II}$ & $1 \mathrm{st}$ & Kanchanaburi, Phrae & 051,215 \\
\hline 6. C. kerrii Airy Shaw & 20 & 10 & 10 & $10 \mathrm{II}$ & $1 \mathrm{st}$ & Phrae & 212 \\
\hline 7. C. kongensis Gagnep. & 20 & 10 & 10 & $10 \mathrm{II}$ & $1 \mathrm{st}$ & Nakhon Ratchasima & 4 \\
\hline 8. C. poilanei Gagnep. & 20 & 10 & 10 & $10 \mathrm{II}$ & $1 \mathrm{st}$ & Sakon nakhon & 337 \\
\hline 9. C. robustus Kurz. & 20 & 10 & 10 & $10 \mathrm{II}$ & Prev. & Chiang Mai & 024 \\
\hline 10. C. roxburghii N. P. Balakr. & 20 & 10 & 10 & $10 \mathrm{II}$ & $1 \mathrm{st}$ & Kanchanaburi & 047 \\
\hline 11. C. stellatopilosus Ohba & 20 & 10 & 10 & $10 \mathrm{II}$ & Prev. & Chacheongsao & 046 \\
\hline 12. C. thorellii Gagnep. & 20 & 10 & 10 & $10 \mathrm{II}$ & $1 \mathrm{st}$ & Sakon Nakhon & 124,175 \\
\hline 13. C. tiglium $\mathrm{L}$. & 20 & 10 & 10 & $10 \mathrm{II}$ & Prev. & Nakhon Pathom & 183 \\
\hline 14. Croton sp. 1 & 20 & 10 & 10 & $10 \mathrm{II}$ & - & Nakhon Ratchasima & 255 \\
\hline 15. Croton sp. 2 & 20 & 10 & 10 & $10 \mathrm{II}$ & - & Chaiyaphum & 81 \\
\hline
\end{tabular}

Coll. No.: P. Soontornchainaksaeng et al., *C. Senakun and W. Thongpuban, Prev.: Previous record, II: bivalent.

\section{Discussion}

The chromosome numbers of the species studied are presented in Table 2 and Fig. 1. All species studied have $2 n=20$, except $C$. hirtus which contains $2 n=16$. Chromosome numbers of $C$. caudatus, C. cascarilloides, C. hutchinsonianus, C. hirtus, C. kerrii, C. kongensis, C. poilanei, C. roxburghii and $C$. thorellii are reported for the first time. The chromosome number revealed for $C$. bonplandianus, C. robustus, C. stellatopilosus and C. tiglium support the previous studied reports (Perry 1943, Missouri Botanical Garden 1999, Soontornchainaksaeng and Chaiyasut 1999). As it is clear from chromosome numbers reported here, that Croton has base number 8 and 10. Chromosomes of microsporocytes of Croton are very well stained with propionocarmine. Most of them are 
clearly paired in bivalent about $1.00-6.00 \mu \mathrm{m}$ in first metaphase cells of $26.67-63.33 \mu \mathrm{m}$. According to most of Croton are used as medicinal plants. The results from the present study are of good interest to point out that Croton has a small genome which could be manipulated or improved simply to obtain high medicinal yield. Moreover, it is quite stable with high fertility in natural habitat. If there is no deforestation, it will continuously be propagated and available for sustainable use.

It seems that decrease in chromosome number has occurred during the course of speciation in the genus, shrub or tree except herbaceous species $C$. bonplandianus have $2 n=20$. But $C$. hirtus an herbaceous species of this genus shows $2 n=16$ which its might be the most advanced than the others.

\section{Acknowledgements}

Appreciation is expressed by the authors to Dr. Kongkanda Chayamarit, Asst. Prof. Chirayupin Chantharaprasong, Mrs. Leena Phuphathanaphong, Mr. Pongsak Polsena and the staff of the Euphorbiaceae Project in Thailand for valuable information. The project was funded by the TRF/BIOTEC Special Program for Biodiversity Research and Training-BRT 140002.

\section{References}

Chayamarit, C., Suntisuk, T., Larsen, K., Welzen, P. V., Esser, H. J., Nanakorn, W., Chantaranothai, P., Boonthavikoon, T., Pooma, R., Phuphathanaphong, L., Chantharaprasong, C. and Larsen, S. 2001. Systematic Study of the Family Euphorbiaceae in Thailand. In: Baimai, V. and Kumhom, R. (eds.). BRT Research Report 2001 Biodiversity Research and Training Program (BRT), Bangkok, Thailand. pp. 78-88.

Missouri Botanical Garden 1999. Index of Plant Chromosome Number. August 11; available from: URL: http://www.mobot.mobot.org/; 1999.

Perry, B. A. 1943. Chromosome number and phylogenetic relationship in the Euphorbiaceae. Amer. J. Bot. 30: 527-543.

Soontornchainaksaeng, P. and Chaiyasut, K. 1999. Cytogenetic investigation of some Euphorbiaceae in Thailand. Cytologia 64: 229-234. 